\title{
A Contemporaneous Sample on the Consumer Brand Preferences for Air Conditioners in West Chennai
}

\author{
Kabirdoss Devi, A. Anupama Juliet, Mohamed Rafic
}

\begin{abstract}
Market situation in India is highly competitive and surviving in the market requires a lot of insight into understanding the customers and providing the right product at the right price at the right place and at the right time. The complexity increases when the product life cycle is shortened due to changing customer taste and preferences, consumerism, rivalry in the market. Exploring the imperative facts on consumer preferences helps the companies to understand the mind-set of customers. This mind set is based on their knowledge about the product (Positioning), attitude (assertiveness), and intention (purpose). In order to understand the need of the customers, one must understand when, where and what customers buy and how frequently they use it. Hence the knowledge on the customer behaviour in the market would definitely enable the companies to understand and decide the expansion plans for the further course of action. This study used a structured questionnaire for the dealer, wholesalers and the retailers of electronic consumer durables.
\end{abstract}

Keywords: brand, consumer, preferences.

\section{INTRODUCTION}

Current market situation in India is highly competitive across all the product segments. Surviving in the market requires a lot of insight into understanding the customers and providing the right product at the right price at the right place and at the right time. Understanding the customer is not an easy exercise because it's the crux of the matter. The demographics and psychographics of the target customers takes an continuous evolution and the study on understanding the customers becomes more complex and needs a frequent study on the given topic. The complexity increases when the product life cycle is shortened due to changing customer taste and preferences, consumerism, rivalry in the market, technological innovations and differentiation of the products.

It is very challenging for the organizations to survive in the light of this scenario and its unwritten instruction for the companies to hold the customers. This becomes more desperate when the companies deal with the home appliances which is tough due to heavy competition. The leading companies like Samsung, Videocon, Sony, LG and other brands introduce various price points with effective segmentation results in faster market expansion and penetration.

Revised Manuscript Received on September 10, 2019.

Dr. Kabirdoss Devi, Assistant Professor (SG), Department of Management Studies, Saveetha Engineering College, Chennai, Tamilnadu, India.

Dr. A. Anupama Juliet, Associate Professor, Department Management

Mr. Mohamed Rafic, II Year MBA, Saveetha Engineering College, Chennai, Tamilnadu, India. (email: kabirdosdevi@saveetha.ac.in) Studies, Saveetha Engineering College, Chennai, Tamilnadu, India.

One of the difficulties faced in sales of air conditioners is that these are expensive for a run-of-the-mill home and expected to have life more than 4 to 5 years. Why is it important to study the current market share of the companies dealing with the sales of Air Conditioners? Because in the post liberalization period, international jumbo brands sneaked a look into Indian markets with an huge expectation. Although the entry of MNC's did not immediately make an initial impact, consumer retention strategies, aggressive marketing strategies and consumer approachable schemes resulted in a precipitous upsurge in their market share. Most of the foreign companies like Sony, Samsung, Panasonic, Philips, LG and Thomson etc are making the Indian brands such as BPL, Videocon, Micromax, Onida miserable.

This study focusses on the consumer preference of air conditioner with respect to product, price, place and promotion and along with this we also need to study the commercial, emotional, sociological features of the buyer and their purposes, assertiveness, perceptions and natures. It is also important to note that an understanding of the consumer preference and emotions are equally an important determinants for the success of the marketers.

\section{INDUSTRY OUTLOOK}

The entire AC market in India boons an uneven situation with close to twenty fivecompanies from all over the world. Daikin, Hitachi, Fujitsu General, Carrier Toshiba, Panasonic, Mitsubishi Electric, Mitsubishi Heavy Industries and Sharp are some of the Japanese Companies. The Korean brands such as Chaebols LG, Samsumg and the Chinese majors Midea, Haier are also very strong players in the Indian Markets. Carrier, Trane and Whirlpool are the American multinational in the field. The Indian players are Voltas, Blue Star, Godrej, Videocon, Fedders, Lloyd and Onida.The Korean brands such as Chaebols LG, Samsumg and the Chinese majors Midea, Haier are also very strong players in the Indian Markets.

\section{EXPECTED GROWTH FOR AIR CONDITIONERS IN 2018}

From January 2018 the prices of ACs has resulted in 4 to $6 \%$ increase due to the up gradation of energy efficiency parameters. The price burden on consumer also increased due to the rise in prices raw materials steel and copper. As a resultant to this, the industry is now scrabbling down the growth expectations. However, the anticipated severity in 
heat throughout the summer season could embark the higher sales despite all the difficulties. The current strategy is that the companies should move on to producing the inverter ACs for the more energy efficiency.

\section{OBJECTIVE OF THE STUDY}

The objective of the study is-

- To study the consumer preferences for Airconditioners on West - Chennai market.

- To find out the relationship between the availability of the brand in the show room and the most selling brands.

- To analyse the purchase patterns and the factors influencing the brand preference of AC.

\section{STATEMENT OF THE PROBLEM}

The growing competition in the industry due to an entry of large number of players in Indian market both from domestic and foreign companies mandates the companies to think over strategies that would attract and retain the customers. The tastes and preferences of the customer changes frequently and it is impossible for the companies to stick on to the traditional methods of business practices. These strategies are not the same persistently and it changes according to the condition and to design aneffective business strategies, it is very much required to appreciate the true-life changing patterns of user behaviour. When purchasing a product, consumers tend to compare the products with other products on the basis of performance, price, warranty and durability. So keeping all these in mind, one has to understand the brands that are doing well in the market and how to overtake them in sales. This needs a complete study on the consumer preferences observed at the retailers point.

\section{NEED OF THE STUDY}

Exploring the imperative facts on consumer preferences helps the companies to understand the mind-set of customers. This mind set is based on their knowledge about the product (Positioning), attitude (assertiveness), and intention (purpose). In order to understand the need of the customers, one must understand when, where and what customers buy and how frequently they use it. Hence the knowledge on the customer behaviour in the market would definitely enable the companies to understand and decide the expansion plans for the further course of action.

\section{SCOPE OF THE STUDY}

This study helps the companies to understand the tastes and preferences of the customers in the given area. This study has an extensive scope as it could be stretched to other areas and make a bigger picture out of it. This study could contribute to a retrospective decision by going through the growth of the other products and its demand.

\section{REVIEW OF LITERATURE}

Janaki, P and Shanthi, (2013) in their study entitled, "Marketing Stimuli in Purchase ofHome Appliances from Customer Perspectives", explains that marketing strategy is the game plan which the firms must adhere to, in order to outdo the competitor or the plans to achieve the desired objective. The people consume things of daily use, and buy these products according to their needs, preferences and buying power. The objectives of the study are to study the purchase decision behaviour relating to home appliances and to analyse customer response to the marketing stimuli of home appliances.

Rajarajan, M and Priyanga, (2013) have written a paper on, "Consumer BehaviourTowards Selected Household Appliances in Ramanathapuram District", the study revealed that lifestyle characteristics have a great impact on the purchase behavior of the clusters. In a consumption environment, a person chooses a product or a brand, which seems to possess a maximum possibility of the definition or elaboration of his life style identity. Alternatively, a person makes a choice in a consumption environment in order to define or actualize his life style, identify it through the products or brands chosen. This paper highlights that, life style determinants of consumer purchase behaviour towards durable products in Ramanathapuram district.

Srinivasa Rao Kasisomayajul, (2013) have written an article entitled, "A Study onCustomer Preference of LG Lap-Top", explains that the consumers? tastes change rapidly. They want new models with the latest features. It is a very hard fight. The competition is on features differentiation, time to market and promotion, basically on every front. The dealer-push and brand pull, both plays a very crucial role. Hence the company concentrate on both fronts equally will have an upper hand over the others.

RatikaRastogia and Sonia Chaudhary, (2012) made their study entitled,"Psychologyand Buying Behaviour of Rural Consumers with Special Reference to Television, Washing Machine and Refrigerator in the Rural Areas of Meerut Region", In this era of competition, understanding the consumer is a necessity for producers. The consumer behavior suggest how individual, groups and organization select, buy, use and dispose of goods, services, ideas or experience to satisfy their needs and wants.

\section{RESEARCH METHODOLOGY}

The study was done on the basis of the response taken from the retailers. The retailers are the observant who make a close watch on the purchasing pattern of the consumers and who can also give us a clear information on the leader of the market. Hence the study's focussed questions on understanding the AC market of West Chennai was shot at the retailers of consumer durable electronic shops. Those retailer shop includes Department stores, Discount stores, Supermarket, Warehouse stores, MOM and Pop Store, Speciality Stores, Malls.

This study through the structured questionnaire taken responses from 50 retailers (retailers from Supermarket to Mom and Pop shops) comprising all the types in order understand the consumer preferences on the white goods particular reference to Air Conditioners. The study considers the consumer's choice of brand based on the price, style, durability, taste and preferencesand warranty. 
Exploratory research consisting of structured questionnaire for the target group of 50 consumer electronics retailers with a convenient sampling. Chi-square, Correlation, percentage and weighted average methods are used.

\section{STATEMENT OF HYPOTHESES}

H0: There is no significant relationship between the brands available in the showroom and the most selling brands.

$\mathrm{H} 1$ : There is a significant relationship between the brands available in the showroom and the most selling brands.

H0: There is no significant difference between the classification of outlet and the sales per month.

H1: There is a significant difference between the classification of outlet and the sales per month.

\section{LIMITATIONS OF THE STUDY}

- This study is limited only to West Chennai and hence the demand and leadership for entire location cannot be generalised.

- Transparency in sharing the information is limited.

- Most of the retailers did not have the patience to answer all the questions.

- Offers given sometimes may result in biased purchase and deviate the study.

\section{ANALYSIS AND INTERPRETATIONS RESULTS}

\section{Total number of years in Dealership}

\begin{tabular}{|c|c|c|}
\hline Categories & No. of Respondents & Percentage \\
\hline 1-3 years & 11 & 22 \\
\hline 4-7 years & 27 & 54 \\
\hline 8-10 years & 5 & 10 \\
\hline 10 years and above & 7 & 14 \\
\hline Total & $\mathbf{5 0}$ & $\mathbf{1 0 0}$ \\
\hline
\end{tabular}

Total Number of years of dealership

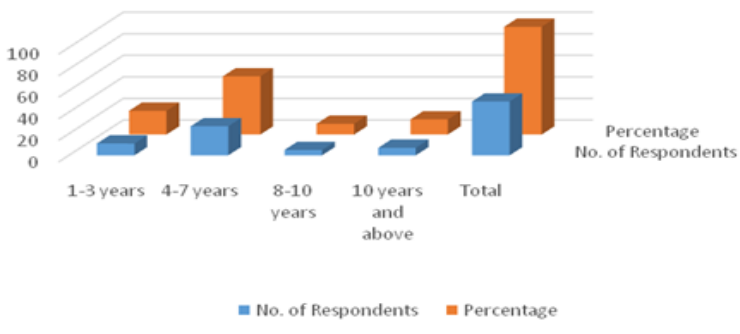

The above table and chart explains the details about the total number of experience in dealership. It is inferred that $54 \%$ of the dealers falls to the category of 4-7 years and $14 \%$ above 10 years.

\section{Classification of outlet-}

\begin{tabular}{|c|c|c|}
\hline Categories & No of Respondents & Percentage \\
\hline Traditional & 10 & 20 \\
\hline Electronic Appliances Store & 37 & 74 \\
\hline Hyper Market & 2 & 4 \\
\hline Large Formal Store & 1 & 2 \\
\hline Total & $\mathbf{5 0}$ & $\mathbf{1 0 0}$ \\
\hline
\end{tabular}

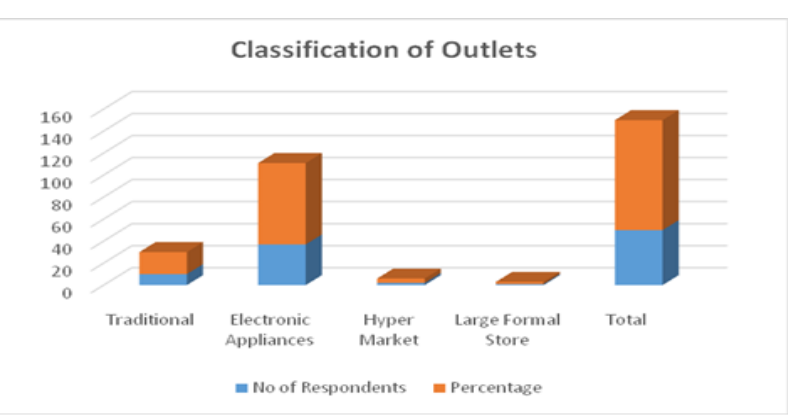

From the above table and chart it is inferred that $74 \%$ and $20 \%$ respondents included for the study were Electronic Appliances retailers and Traditional dealers respectively. Hypermarket and Large formal store retailers participated very less.

\section{Sales per month-}

\begin{tabular}{|c|c|c|}
\hline Categories & No. of Respondents & Percentage \\
\hline $0-20$ & 13 & 26 \\
\hline $20-50$ & 26 & 52 \\
\hline $50-100$ & 10 & 20 \\
\hline $100 \&$ above & 1 & 2 \\
\hline Total & $\mathbf{5 0}$ & $\mathbf{1 0 0}$ \\
\hline
\end{tabular}

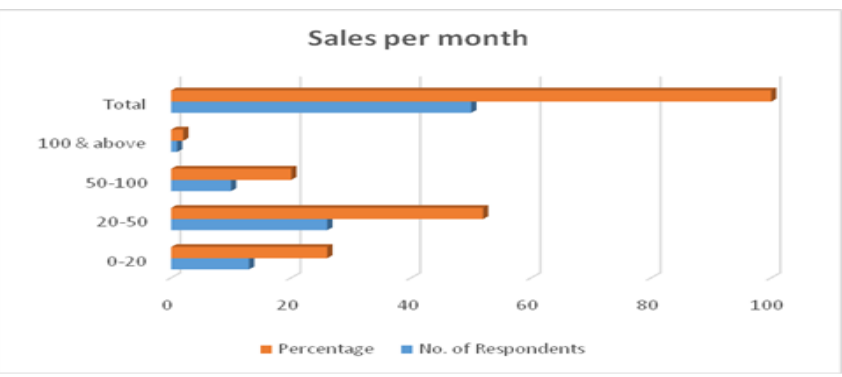

From the above table and chart it is inferred that $52 \%$ of the respondents make $20-50$ pieces of air conditioners in a month. $20 \%$ of the retailers are selling close to 50-100 pieces of air conditioners in a month whereas only $2 \%$ are able to sell more than 100 pieces. But it has to be also observed that equally $26 \%$ of retailers are able to sell only 0 to 20 pieces of air-conditioner in a month.

\section{Sales of AC in terms of tonnes}

\begin{tabular}{|c|c|c|}
\hline Categories & No. of Respondents & Percentage \\
\hline $1-2$ tonnes & 23 & 46 \\
\hline $2-3$ tonnes & 16 & 32 \\
\hline $3-4$ tonnes & 10 & 20 \\
\hline $4-5$ tonnes & 0 & 0 \\
\hline 5 tonnes \& above & 1 & 2 \\
\hline Total & 50 & 100 \\
\hline
\end{tabular}




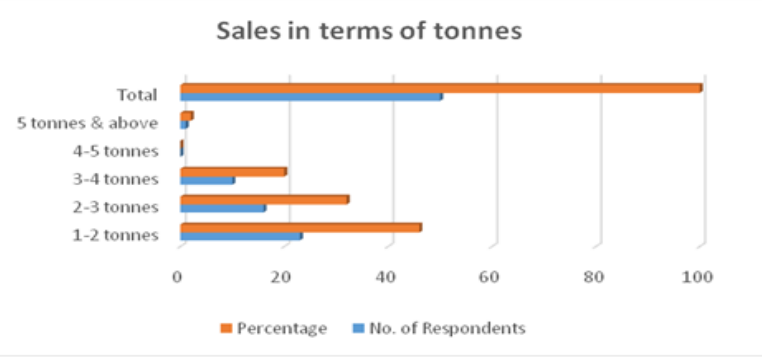

From the above table and chart it is inferred that $46 \%$, $32 \%$ and $20 \%$ of the sales are happening majorly for 1-2 tonnes, 2-3 tonnes and 3-4 tonnes respectively. No one bought $4-5$ tonnes in this zone and only $2 \%$ of sales made in the category of 5 tonnes and above.

5. Brands of air conditioner available in the show room-

\begin{tabular}{|c|c|c|}
\hline Categories & No. of Respondents & Percentage \\
\hline Voltas & 13 & 26 \\
\hline Samsung & 17 & 34 \\
\hline Panasonic & 4 & 8 \\
\hline LG & 15 & 30 \\
\hline Haier & 0 & 0 \\
\hline Whirlpool & 1 & 2 \\
\hline O General & 0 & 0 \\
\hline Total & 50 & 100 \\
\hline
\end{tabular}

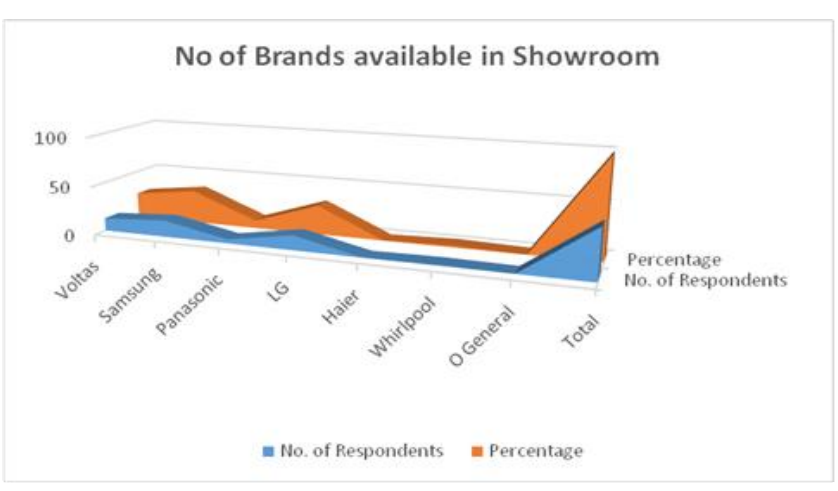

From the above table and chart it is inferred that the Voltas, Samsung and LG are the most the available brands in the showroom with a percentage of $26 \%, 34 \%$ and $30 \%$ respectively. Panasonic and Whirlpool recorded $8 \%$ and $1 \%$ respectively. Haier and General did not record any presence in this particular region.

\section{Most Selling Brand}

\begin{tabular}{|c|c|c|}
\hline Categories & No. of Respondents & Percentage \\
\hline Voltas & 13 & 26 \\
\hline Samsung & 18 & 36 \\
\hline Panasonic & 6 & 12 \\
\hline LG & 13 & 26 \\
\hline Haier & 0 & 0 \\
\hline Whirlpool & 0 & 0 \\
\hline O General & 0 & 0 \\
\hline Total & 50 & 100 \\
\hline
\end{tabular}
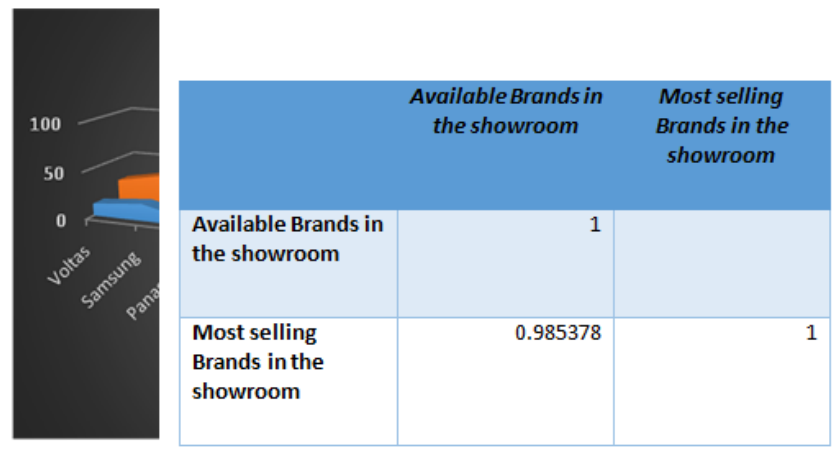

From the above table and chart it is inferred that the most selling brands are the Voltas, Samsung, Panasonic and LG with 26\%, 36\%, 12 and 26\% respectively. Other brands have not opened and it may be due the non-availability of the brand.

\section{Correlation Analysis:}

Relationship between Brands in showroom and most selling brands-

\begin{tabular}{|c|c|c|}
\hline Brand Category & $\begin{array}{l}\text { Available Brands in the } \\
\text { showroom }\end{array}$ & $\begin{array}{l}\text { Most selling Brands in the } \\
\text { showroom }\end{array}$ \\
\hline Voltas & 13 & 13 \\
\hline Samsung & 17 & 18 \\
\hline Panasonic & 4 & 6 \\
\hline LG & 15 & 13 \\
\hline Haier & 0 & 0 \\
\hline Whirlpool & 1 & 0 \\
\hline O General & 0 & 0 \\
\hline Total & 50 & 50 \\
\hline
\end{tabular}

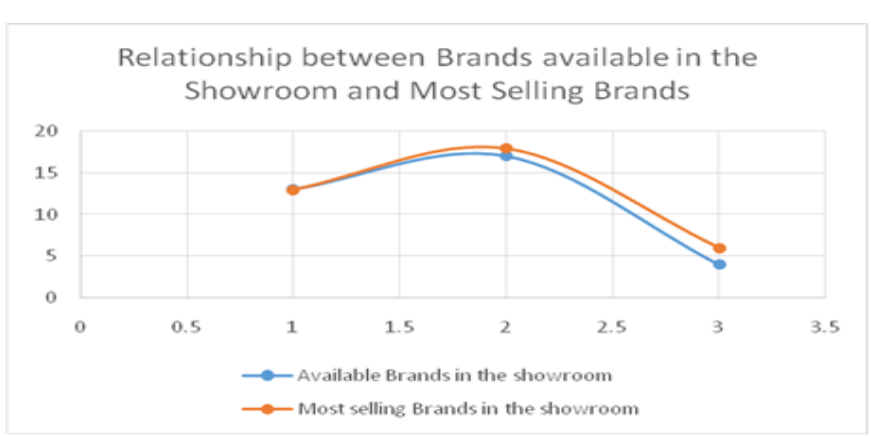

There is a significant positive relationship between the brands available in the showroom and the most selling brands.

8. Regression and Anova Test:

Difference between classification of outlet and sales per month- 


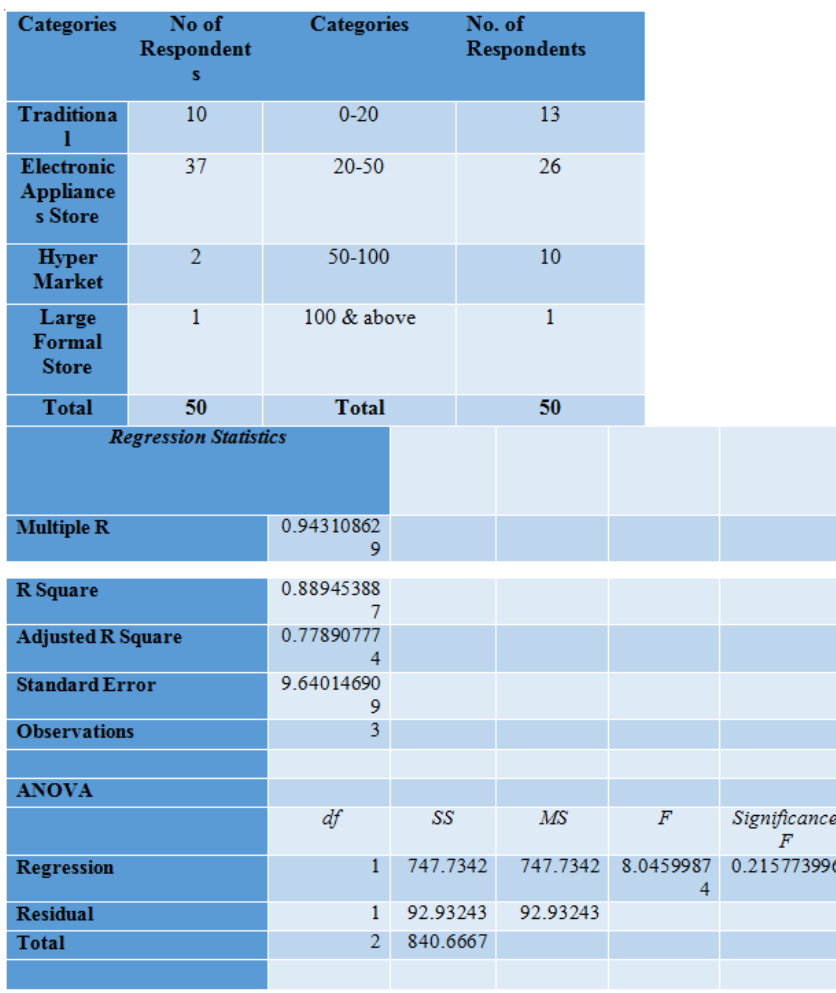

There is no significant difference between the classification of the stores and the number of sales per month.

\section{FINDINGS FROM THE STUDY}

1. It has been observed that half of the dealers are having 4-7 years minimum and more than 10 years maximum.

2. It is found from the study that $3 / 4$ th of the buyers prefer Electronic Appliances Stores and the rest traditional stores.

3. It is evidently shown that the 20-50 pieces of ACs are sold in a month which $52 \%$ of the total sales among the retailers. But minimum 1-20 pieces are sold and the maximum 1 or 2 retailers sells more than 100 pieces in a month.

4. 1-2 tonnes are the highest selling ACs next to 2-3 tonnes. Very less sales are seen in 5 tonnes.

5. Voltas, Samsung, LG and Panasonic are the most available brands in the showrooms.

6. Samsung has recorded the highest sales with Voltas and LG following the trend.

7. There is a positive relationship between the availability of the brand in the showroom and the most selling brand.

8. There is no significant difference between the type of the outlet and the sales per month.

\section{SUGGESTIONS}

1. It is suggested that companies should focus on making their brands available in the stores hence there is a significant relationship between the availability of the brand and the selling of the brands. Haier, Panasonic and Whirlpool should concentrate on making their products available in all the stores.
2. Companies should target the Electronic Appliances Stores and Traditional Stores since sales has recorded the highest.

3. Since there is no significant difference between the outlet and the sales, companies should market their brand in all the retails.

4. This study is limited to West Chennai and in this region consumers prefer lower tonne ACs and hence attention should be paid in that segment.

\section{CONCLUSION}

This study enables the company to identify the possible strategies to attract the customers and make the prospective sales in this region. It is also advisable that companies should focus more availability of their products to the customers reach. Tastes and preferences changes frequently and hence persistent focus on improving the product in line with the customer is the must.

\section{REFERENCES}

1. ArashShahin, Ali Kazemi and HamzehKazemiMahyari (2012) "How Consumer?s Perception of Country of Origin Affects Brand Equity: A Case Study in Iran", Middle-East Journal of Scientific Research, Vol.12, Issue.6, pp.878-885.

2. Janaki, P and Shanthi, P (2013) "Marketing Stimuli In Purchase Of Home Appliances From Customer Perspectives", International Journal of Sales \& Marketing Management Research and Development (IJSMMRD), Vol. 3, Issue 2, pp. 23-30.

3. Rajarajan, $\mathrm{M}$ and Priyanga, $\mathrm{T}$ (2013) "Consumer Behaviour Towards Selected Household Appliances in Ramanathapuram District", Primax International Journal of Commerce andManagement Research, Vol. 1, Issue No. 1, pp.1-10.

4. RatikaRastogia and Sonia Chaudhary (2012) "Psychology and Buying Behaviour ofRural Consumers with Special Reference to Television, Washing Machine and Refrigerator in the Rural Areas of Meerut Region", International Journal of Trade and CommerceIIARTC, Vol.1, No. 2, pp. 249-259.

5. Srinivasa Rao Kasisomayajula (2013) "A Study on Customer Preference of LG Lap-Top", International Journal Of Computational Engineering Research (ijceronline.com) Vol. 3 Issue. 3, pp.234-237. 